\title{
INDIVIDUALIOS KINEZITERAPIJOS PROGRAMOS POVEIKIS APATINIŲ GALŪNIỤ MOBILUMUI PO GŪŽDUOBĖS IR ŠLAUNIKAULIO OSTEOTOMIJOS: ATVEJO ANALIZE்
}

\author{
Laima Liaudanskyte் ${ }^{1}$, Algimantas Čebatorius ${ }^{2}$, Daiva Mockevičiené $\dot{e}^{1}$, \\ Gražina Bokūnaitė $\dot{1}^{1}$, Saulius Knystautas ${ }^{3}$ \\ ${ }^{1}$ Klaipédos universiteto Sveikatos mokslu fakulteto Holistinès medicinos ir reabilitacijos katedra, \\ ${ }^{2}$ Klaipedos universitetine ligoninè, Traumatologijos departamento Traumatologijos skyrius, \\ ${ }^{3}$ Lietuvos sveikatos mokslu universiteto Medicinos fakultetas
}

Raktažodžiai: klubo sąnario displazija, gūžduobès ir šlaunikaulio osteotomija, apatinių galūnių mobilumas.

\begin{abstract}
Santrauka
Klubo sąnario displazija (KD) - tai dèl nenormalaus gūžduobès ir šlaunikaulio galvutės sąlyčio sutrikęs klubo sąnario formavimasis arba neišsivystęs ir dèl to nestabilus klubo sąnarys. Jaunų asmenų klubo sąnarys yra susiformavęs, todèl pastebejus ligą ar pajutus jos simptomus paauglystėje ir vèliau reikalinga gūžduobès ir šlaunikaulio osteotomija. Tyrimo metu buvo siekiama nustatyti individualios kineziterapijos programos poveikị apatinių galūnių mobilumui po gūžduobès ir šlaunikaulio osteotomijos.

Tyrimas atliktas 21 metu pacientui, kuriam 2018 metais Madrido (Ispanija) Quirónsalud universitetinejje ligoninejje buvo atlikta gūžduobès ir šlaunikaulio osteotomija. Kineziterapijos poveikis pacientui buvo vertinamas pusiau struktūrinio interviu metodu, naudojant standartizuotą Madrido popiežiškojo Comillas universiteto klausimyną, atliekant sąnario amplitudès testavimą goniometru, raumenų tonuso vertinimą Ashworth skale, raumenų jègos vertinimą rankiniu dinamometru. Asimetrijos testas atliktas vaizdo analizės programėle My Jump 2. Vertinimas atliktas prieš kineziterapiją ir po jos. Kineziterapijos metu tiriamojo skausmas kas 2 savaites buvo vertinamas VAS skausmo balais, jam atlikta manualinè terapija, fizioterapija, minkštujų audinių masažas.

Po kiekvieno kineziterapijos vertinimo gauti reikšmingi rezultatai. Pažeisto sąnario amplitudès testavimas goniometru parodè klubo lenkimo padidèjimą 18 laipsnių. Ryškiausi raumenų tonuso rezultatai: klubo sąnario lenkimas
\end{abstract}

sumažèjo nuo 2 iki 1 balo, tiesimas sumažèjo nuo $1+$ iki 0 balo, raumenu jègos - klubo lenkimo padidejjo nuo 69 iki 90 kilogramu. Asimetrijos testas buvo atliekamas du kartus ir antrasis testavimas parode siekiamą rezultatą ( 9 proc.). Pirmają savaitę pacientas savo skausmą ịvertino 6 VAS balais, 9 savaitę skausmas sumažejo iki 3 VAS balų. Remiantis vertinimo rezultatais, galima teigti, jog paciento apatinių galūnių mobilumas po kineziterapijos pagerejo. Pacientas tapo pakankamai pajègus ir galintis grịžti ị sportinio pasirengimo etapą.

\section{İvadas}

Klubo sąnario displazija (KD) - tai dèl nenormalaus gūžduobės ir šlaunikaulio galvutès sąlyčio sutrikęs klubo sąnario formavimasis arba neišsivystęs ir dèl to nestabilus klubo sąnarys. Ši, dažniausiai ịimta liga, nepastebèta naujagimystejje ir vaikysteje, turi didelį poveikị paauglystėje. Nesant simptomų, ji gali trukti daugybę metų. Jaunų asmenų klubo sąnarys yra susiformavęs, todèl pavėluotai pajutus simptomus ir pastebejjus ligą, reikalinga gūžduobès ir šlaunikaulio osteotomija. Šios operacijos tikslas - visiškai atskirti gūžduobę nuo dubens, suteikti jai taisyklingą padètị ir fiksuoti sraigtais [1]. Viena iš svarbiausių reabilitacijos rūšių atkurti apatinių galūnių mobilumą po operacijos yra kineziterapija. Kineziterapijos metu didinamos sąnario amplitudès, stiprinama raumenu jèga, koordinacija bei pusiausvyra. Tai svarbiausias reabilitacijos etapas, kurio nesant nebūtų atkurtas paciento apatinių galūnių mobilumas, o skausmas būtų jaučiamas ilgesnį laiką.

Tyrimo tikslas - nustatyti individualios kineziterapijos programos poveikị apatinių galūnių mobilumui po gūžduobès ir šlaunikaulio osteotomijos. 


\section{Tyrimo medžiaga ir metodai}

Tyrime dalyvavo 21 metų pacientas, kuris $2018 \mathrm{~m}$. spalio-gruodžio mėnesiais lankèsi Madrido (Ispanija) Quirónsalud universitetinėje ligoninėje po dešiniosios gūžduobės ir šlaunikaulio osteotomijos. Tiriamasis yra profesionalus futbolo žaidèjas, dèl ịvykusios traumos nutraukęs sportinę veiklą. Reabilitacija (REAB) jam svarbi, kad galètu pradèti sportinio pasirengimo etapą. REAB programoje: kineziterapija, manualinè terapija, fizioterapija bei minkštujų audinių masažas.

Pirmają reabilitacijos dieną pacientui buvo pateiktas pusiau struktūrinis interviu. Klausimynas sudarytas pagal standartizuotą Madrido popiežiškojo Comillas universiteto klinikinès analizès formą. Šis klausimynas naudojamas vertinti paciento bendrają sveikatą, gyvenimo būdą bei išsiaiškinti ligos istoriją, ji sudare 30 atviro tipo klausimų. Pacientui buvo taikoma standartizuotų testų analizè, kuri susideda iš sąnario ir raumenų būklès ịvertinimo bei sąnario asimetrijos vertinimo vaizdo analizès programėle My Jump 2. Sąnario amplitudès testavimas goniometru naudotas nustatyti, ar paciento sąnario būklè pooperaciniu laikotarpiu atitinka nustatytas normas. Raumenų būklei tirti pasirinktas raumenu tonuso ịvertinimas Ashworth skale, o raumenu jègos ìvertinimui - dinamometras. Ashworth skalès testo rezultatai vertinami nuo 0 iki 4 balų sistema, o dinamometro testo rezultatai - atsižvelgiant ị paciento lytị bei amžiaus grupę. Asimetrijos testui naudota vaizdo analizès programélè My Jump 2. Programėlé

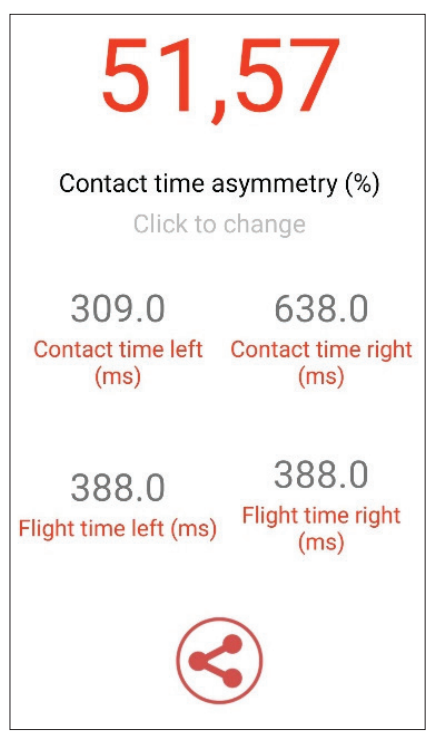

1 pav. Vaizdo analizès programèlès My Jump 2 vaizdas geba matuoti tikslų šuolio aukštį, apskaičiuoja jègos greitị, matuoja kontakto su žeme laiką, standumą, reaktyvų jègos indeksą (RSI) ir kojų asimetriją (1 pav.). Kineziterapijos metu paciento kas 2 savaites buvo prašoma įvertinti jaučiamą skausmą vaizdo analogijos skalès (VAS) balais nuo 0 iki 10.

\section{Rezultatai}

Testavimas (išskyrus asimetrijos testą) pacientui atliktas10 dienų po operacijos pirmają REAB dieną ir po 2,5 mènesio intensyvios

1 lentelè. Goniometrinių matavimų rezultatai prieš ir po kineziterapijos

\begin{tabular}{|l|c|c|c|}
\hline \multirow{2}{*}{ Judesiai per klubo sąnarị } & \multicolumn{3}{|c|}{ Goniometriniai matavimai } \\
\cline { 2 - 4 } & $\begin{array}{c}\text { Prieš kinezitera- } \\
\text { piją (10 dienų po } \\
\text { operacijos) }\end{array}$ & $\begin{array}{c}\text { Po 2,5 mėn. } \\
\text { kinezitera- } \\
\text { pijos }\end{array}$ & Norma \\
\hline Lenkimas (fleksija) & $100^{0}$ & $118^{0}$ & $120^{0}$ \\
\hline Tiesimas (ekstenzija) & $11^{0}$ & $25^{0}$ & $30^{0}$ \\
\hline Atitraukimas (abdukcija) & $38^{0}$ & $47^{0}$ & $45^{0}$ \\
\hline Pritraukimas (addukcija) & $15^{0}$ & $24^{0}$ & $30^{0}$ \\
\hline Vidinė rotacija & $13^{0}$ & $30^{0}$ & $45^{0}$ \\
\hline Išoriné rotacija & $60^{0}$ & $62^{0}$ & $45^{0}$ \\
\hline
\end{tabular}

2 lentelè. Raumenų tonuso Ashworth skalès rezultatai

\begin{tabular}{|l|c|c|}
\hline \multirow{2}{*}{ Atliekamas judesys } & \multicolumn{2}{|c|}{ Ashworth skalės rezultatas } \\
\cline { 2 - 3 } & $\begin{array}{c}\text { Prieš kineziterapiją } \\
\text { (10 dienų po operacijos) }\end{array}$ & $\begin{array}{c}\text { Po 2,5 mėn. } \\
\text { kineziterapijos }\end{array}$ \\
\hline Klubo sąnario lenkimas & 2 & 1 \\
\hline Klubo sąnario tiesimas & $1+$ & 0 \\
\hline Klubo sąnario atitraukimas & $1+$ & 1 \\
\hline Klubo sąnario pritraukimas & 1 & 0 \\
\hline Kelio sąnario lenkimas & 0 & 0 \\
\hline Kelio sąnario tiesimas & 0 & 0 \\
\hline
\end{tabular}

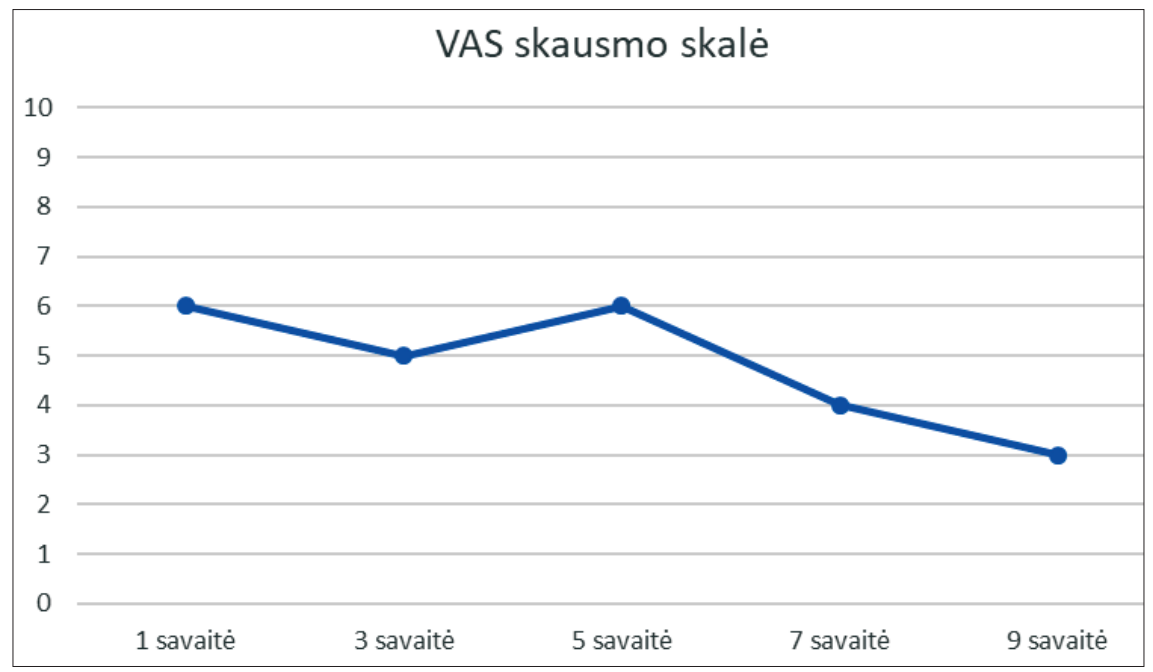

2 pav. Skausmo pokyčių VAS balais grafinis vaizdas 
REAB programos vykdymo. Pirmojo testavimo metu sąnario būklès įvertinimo didžiausias rezultatas matomas lenkime per klubo sąnarị. Pradinis rezultatas siekè $100^{\circ}$, po REAB $118^{\circ}$, kai goniometrinių matavimų normos fleksijoje yra $120^{\circ}(1$ lentelè) [2]. Didžiausias raumenų būklès, įvertintos Ashworth skale, pokytis matomas klubo lenkime ir tiesime. Klubo lenkimo pradinis rezultatas 2 balai, po REAB -1 balas. Klubo tiesimo pradinis rezultatas +1 balas, po REAB -0 balų ( 2 lentelè) [3]. Vertinant raumenų jègą rankiniu dinamometru, didžiausia pažanga matoma klubo lenkimo supinuotoje padètyje (KL-SUP). Pradinis rezultatas siekè $69 \mathrm{~kg}$, po REAB 90 kg, kai norma 47 kg (3 lentelè) [4]. Visų standartizuotų testų rezultatai didžiausi buvo lenkimo per klubo sąnarị. Asimetrijos testas pirmą kartą buvo atliktas praejus 8,5 savaitès po REAB. Pacientas neatitiko nustatytų normų $(>10 \%)$, surinkdamas 10 proc., todèl testavimas buvo kartojamas po 1 papildomos REAB savaitès. Atlikus testavimą antrą kartą, tiriamasis atitiko nustatytas normas, surinkęs 9 proc., todèl buvo leista grịžti ị sportinị fizinio pasirengimo etapą (4 lentelè) [5]. Kineziterapijos metu kas 2 savaites tiriamojo buvo prašoma įvertinti savo skausmą VAS balais nuo 0 iki 10. Pirmają savaitę tiriamojo skausmas siekè 6 balus, tačiau 9 savaitę sumažèjo iki 3 balų. Skausmas pakito, pakeitus kineziterapijos programą (2 pav.).

\section{Diskusija}

Šlaunikaulio ir gūžduobès osteotomijos operacija itin retai atliekama Lietuvoje. Dèl šios priežasties dar nèra pritaikytos kineziterapijos programos. Ispanijos Madrido ligoninejje pacientui, turinčiam klubo sąnario displaziją, pritaikyta individuali kineziterapijos programa. Aktualu ir

3 lentelè. Raumenų jẻgos ịvertinimo rankiniu dinamometru rezultatai

\begin{tabular}{|c|c|c|c|}
\hline \multirow{2}{*}{$\begin{array}{l}\text { Atliekamas } \\
\text { judesys ir } \\
\text { padètis }\end{array}$} & \multicolumn{2}{|c|}{ Raumenų jègos rezultatas } & \multirow{2}{*}{$\begin{array}{c}\text { Raumenų } \\
\text { jègos } \\
\text { norma, kg }\end{array}$} \\
\hline & $\begin{array}{l}\text { prieš kinezite- } \\
\text { rapiją, kg (10 } \\
\text { dienų po opera- } \\
\text { cijos) }\end{array}$ & $\begin{array}{l}\text { po } 2,5 \text { mèn. } \\
\text { kineziterapi- } \\
\text { jos, kg }\end{array}$ & \\
\hline KL-SUP & 69 & 90 & 47 \\
\hline KT-PP-VK & 89 & 105 & 48 \\
\hline KT-PP-NK & 101 & 118 & 51 \\
\hline KA-ŠP & 53 & 67 & 28 \\
\hline KP-ঙ̌P & 43 & 60 & 32 \\
\hline
\end{tabular}

4 lentelè. Asimetrijos testo rezultatai

\begin{tabular}{|l|c|c|}
\hline Testo atlikimo laikas & $\begin{array}{c}\text { Paciento } \\
\text { rezultatas }\end{array}$ & $\begin{array}{c}\text { Asimetrijos } \\
\text { testo norma }\end{array}$ \\
\hline Po 8,5 savaičiu kineziterapijos & $10 \%$ & $>10 \%$ \\
\cline { 1 - 2 } Po 9,5 savaičiu kineziterapijos & $9 \%$ & \\
\hline
\end{tabular}

tai, jog vaizdo analizès programèlè My Jump 2 dar nebuvo naudojama Lietuvoje.

Kineziterapijos intensyvumo poveikiui po gūžduobès ir šlaunikaulio osteotomijos pritaria ir gamtos mokslų daktaras R. Steven, teigdamas, jog kineziterapijos vaidmuo yra gyvybiškai svarbus, kad būtų sumažintas skausmas, atkurtas apatinių galūnių mobilumas, o pacientas galètų grịžti i sportinę veiklą [6].

Vertinant paciento standartizuotų testų analizès rezultatus, pastebèta didelè fizinio pasirengimo pažanga. Nesant kineziterapijos bei kitų REAB procedūrų, toks pokytis nebūtų imanomas.

\section{Išvados}

Tyrimo pradžioje (10 dienų po operacijos) tiriamojo bendroji sveikatos būklè bei fizinis pasirengimas neatitiko norminių rodiklių, tačiau per 2,5 mènesio intensyvios REAB buvo atkurtas paciento fizinis pajègumas ir galimybè grižti i sportinio pasirengimo etapą.

\section{Literatūra}

1. Degutis G., Butėnas P., Kervys L. Displazinių klubų sąnarių endoprotezavimo atokūs rezultatai. Sveikatos mokslai, 2015;25(1):39-43.

https://doi.org/10.5200/sm-hs.2015.006

2. Clarkson MH. Musculoskeletal assesment: joint motion and muscle testing. Philalephia, USA, 2013.

3. Pocienė M. Kineziterapijoje taikomi funkciniai testai. Kaunas: Vitae Litera, 2013:52.

4. Thorborg K, Petersen J, Magnusson SP, Hölmich P. Clinical assessment of hip strength using a hand-held dynamometer is reliable. Scand J Med Sci Sports, 2010;20(3):493-501. https://doi.org/10.1111/j.1600-0838.2009.00958.x

5. Balsalobre-Fernández C, Glaister M, Lockey RA. The validity and reliability of an iPhone app for measuring vertical jump performance. J Sports Sci 2015;33(15):1574-9. https://doi.org/10.1080/02640414.2014.996184

6. Tippett SR. Returning to sports after periacetabular osteotomy for developmental dysplasia of the hip. N Am J Sports Phys Ther 2006 1(1): 32-39.

\section{THE EFFECT OF THE INDIVIDUAL PHYSIO- THERAPY PROGRAMME ON LOWER LIMB MOBILITY AFTER THE ACETABULUM AND FEMORAL OSTEOTOMY: A CASE ANALYSIS L. Liaudanskytè, A. Čebatorius, D. Mockevičienė, G. Bokūnaitè, S. Knystautas}

Keywords: hip joint dysplasia, acetabulum and femoral osteotomy, lower limb mobility.

Summary

Introduction. Hip dysplasia (hip) is a disorder, caused by the 
interruption of normal contact between acetabulum and the femoral head, the formation of a hip joint or undeveloped and therefore unstable hip joint. In young people, the hip joint is already formed, so after noticing the disease and feeling the symptoms, the only solution remains during this period - acetabulum and femoral osteotomy surgery. The aim of the research was to determine the effect of physiotherapy exercises on lower limb mobility after acetabulum and femoral osteotomy surgery.

Methods. In this reaserch participated 21-year-old patient, who had an acetabulum and femoral osteotomy surgery in 2018 at Quirónsalud Hospital of the Universitario de Madrid in Spain. The patient was assessed by: a semi-structured interview, according to a questionnaire set up by the University of Comillas Pontificia in Spain, also the range of motion testing, muscle tone assessment with Ashworth scale, muscle strength assessment with hand-held dynamometer and "Asymmetry test" with video analysis app "My Jump 2". All physiotherapy assessments are performed before and after physiotherapy. Also, during physiotherapy, the subject was assessed on the VAS pain scale every 2 weeks. In addition to physiotherapy, the patient was given manual therapy, physiotherapy and soft tissue massage.
Results. Significant results were seen after each evaluation of physiotherapy. The greatest result of the range of motion testing of the damaged joint with a goniometer was in the hip flexion, it increased $18^{\circ}$. In the assessment of muscle tone, the most pronounced results are seen in the flexion of the hip joint (decreased from 2 to 1 point) and extention (decreased from $1+$ to 0 points), muscle strength - hip flexion (increased from 69 to 90). The "asymmetry test" was performed twice and the desired result of $9 \%$ was achieved after the second time. In the first week, the patient rated his pain (VAS 0-10) at 6 points, but by the week 9 the pain had dropped to 3 points.

Conclution. Based on the results obtained from all physiotherapy evaluations, it can be stated that the mobility of the patient's lower extremities improved. The patient became sufficiently capable of returning to the stage of sports preparation.

Correspondence to: daiva.mockeviciene@gmail.com

Gauta 2020-11-27 